\title{
Economic Feasibility of Plastic Shelter Tomato Production Method under Rain-Fed in Fogera Plain, North Western Ethiopia
}

\author{
Misganaw Anteneh Tegegne, Endayen Melaku, Seged Ayichew \\ Ethiopian Institute of Agricultural Research
}

\begin{abstract}
The research intervention was conducted in Fogera plain commonly known and consists of (Fogera, Dera and Libokemkem districts) of South Gondar Zone to evaluate economic feasibility of the new tomato production method using plastic shelter under rain fed production condition. Two types of improved tomato varieties were used known as Melkasalsa and melkashola, each variety within $200 \mathrm{~m}^{2}$ plots of land. A sum of $5 \mathrm{kebeles} / \mathrm{sites}$ and 11 technology beneficiaries (farmers) were addressed under this intervention in three districts. Data on input costs, benefits among other parameters were collected and recorded through intensive field observation and follow up, field days, focused group discussion. Quantitative types of data such as yield, participants in different events through field day, training and exchange visit and qualitative types of data like feed backs, farmers' perception and preference on demonstrated rice technologies. The use of plastic shelter in tomato production under rain-fed condition had considerable impact on yield performance. The relative yield advantage of tomato production using plastic shelter is better than without shelter production. Regarding profitability issues, the result shows, tomato production using plastic shelter was by far profitable than without shelter production in both varieties. The estimated value of marginal rate of return with shelter production was greater than one for both varieties. An investment of one Ethiopian Birr (ETB) on new production method using plastic shelter could generate additional net income of 20 ETB and 14 ETB from melkasalsa and melkashola varieties, respectively. Hence farmers and respective bodies need to strengthen production of tomato in the rainy season using shelter to get more returns and enhance their livelihood and economic benefits.
\end{abstract}

Keywords: Marginal rate of return, Melka Salasa, Melka shola, Partial budget analysis, Plastic shelter, rain-fed DOI: $10.7176 / \mathrm{JESD} / 13-1-02$

Publication date: January $31^{\text {st }} 2022$

\section{Introduction}

Tomato production in an open field under rain fed is difficult mainly due to high incidence of diseases. In addition, production of tomatoes during the rainy season is limited by unfavorable conditions such as hail, high rainfall and flooding and strong winds. These conditions, causing flower and immature fruit drop and damage to the foliage, can significantly reduce tomato yields. Plastic rain shelters by avoiding leaf contact with moisture would help to control disease development. Moreover, rain shelters protect tomato plants against the impact of heavy rainfall and prevent frequent periods of leaf wetness. Sometimes the use of rain shelters can make a difference between harvesting a good crop and harvesting no crop at all (Palada et al, 1994). The use of rain shelter would therefore help to minimize or avoid the use of fungicides to control tomato diseases. Fungicides are costly and hazardous to human life and the environment in general. Tomato production during rainy season in open field condition is very difficult mainly due to serious disease attack. Integrated approaches for rain fed tomato production in open field condition through the use of disease tolerant varieties and applications of fungicides were evaluated by Fogera Research Center in 2016. It was however compulsory to use repeated and massive applications of fungicides, whose direct and residual effect is, however hazardous to human health and the environment in general (Dessie Getahun, 2015). It is therefore critical to devise appropriate production system affordable by growers that could avoid or minimize the use of fungicides and ensure constant supply of fresh tomatoes throughout the year with an uninterrupted production both in the dry and rainy seasons. Rainy season tomato production under low-cost plastic shelter by avoiding direct contact of rain with tomato foliage avoids favorable condition for disease development. This practice is therefore helpful to produce tomatoes without the use of fungicides contributing towards ensuring continuous production and constant supply of fresh tomatoes throughout the year (Dessie Getahun,2019). Furthermore, by improving the microclimatic condition such as raising the temperature under the shelter, favorable environment for the production of high tomato yield with superior quality will be created. This technology is widely practiced elsewhere in the world to produce fresh tomatoes with high quality and yield in the rainy period.

\section{Objectives}

$>$ To evaluate impacts of the use of plastic shelter on relative yield performance for rain fed tomato production

$>$ To evaluate economic feasibility of the use of plastic shelter for rain fed tomato production 


\section{Methodology}

\subsection{Description of study areas}

The research intervention was conducted in three districts of South Gondar zone of Amhara region. South Gondar zone is known with huge potential in horticultural crop production using rainfed and irrigation in the off-season. It has 12 districts from which three districts (Fogera, Dera and Libokemkem) were the targets of this intervention. This Zone has a total population of 2,051,738 and an increase of 16\% over the 1994 census, of whom 1,041,061 are men and 1,010,677 women. With an area of 14,095.19 square kilometers. the average rural household has 1 hectare of land (compared to the national average of 1.01 hectare of land and an average of 0.75 for the Amhara Region) and the equivalent of 0.6 heads of livestock. $14 \%$ of the population is in non-farm related jobs. Fogera is one of the districts in the Amhara region of North west Ethiopia. Fogera is part of the South Gondar Zone. The district is bordered on the south by Dera district, on the West by Lake Tana on the North by the Erib river which separates it from Libo Kemkem district, on the Northeast by Ebinat and on the East by Farta. The administrative center for this district is Wereta City which is 618 kilo meters away from the capital of Addis abeba, Ethiopia. The altitude of this district ranges from 1774 to 2415 meters above sea level. A survey of the land in Fogera shows that $44.2 \%$ is arable or cultivable and another $20 \%$ is irrigated, $22.9 \%$ is used for pasture, $1.8 \%$ has forest or shrubland, $3.7 \%$ is covered with water, and the remaining $7.4 \%$ is considered degraded or other. Some 490 square kilometers of land adjacent to Lake Tana is subject to regular and severe flooding. The heavy rain caused Lake Tana to overflow its banks, making thousands of people homeless. It is also known with Fogera cattle bred. Dera district is one of the districts in the Amhara Region of Ethiopia and also part of the south Gondar Zone, Dera district is bordered on the South by the Abay River which separates it from the West Gojjam. A survey of the land in this district shows that $46 \%$ is arable or cultivable, $6 \%$ pasture, $1 \%$ forest or shrubland, $25 \%$ covered with water and the remaining $25.9 \%$ is considered degraded or other. Teff corn, sorghum, cotton and sesame are important cash crops. Libo Kemekem is one of the districts in the Amhara Region of Ethiopia. Part of the South Gondar Zone, it is bordered on the South by the Erib. A survey of the land in this district shows that $51 \%$ is arable or cultivable, $8.3 \%$ pasture, $5.9 \%$ forest or shrubland, $17.98 \%$ covered with water, and the remaining $17.03 \%$ is considered degraded or other. Teff, corn, sorghum, cotton and sesame are important cash crops.

\subsection{Site and farmers' selection}

Farmers and sites were selected based on strong willingness of farmers and suitability of the areas for tomato production. The other criteria for farmer's selection were knowhow about the two cultivars (Melka salsa and Melka Shola), and those who can contribute materials for shelter construction. 2 kebeles from libokemkem, 2 kebeles from Fogera and one kebele from Dera districts were selected based on their potential and suitability of tomato production. A total of 11 farmers were selected under this research intervention.

\subsection{Planting materials and inputs used}

Melka salsa and melka shola varieties were used for this intervention. A single bed type with an A-shaped Shade has been constructed as soon as the seedlings are planted. Local materials like wood and bamboo have been used for construction of temporary rain shelters and staking. There were four treatments (each variety with shelter and without shelter), cost data collection sheet as tool prepared for each farmer. After transplanting, full practices including chemical application and other agronomic practices have been implemented.

\subsection{Data collection}

Both qualitative and quantitative types of data were collected through direct field observation and measurements, interviews, Focused Group Discussion. Quantitative data such as yield data field day participants by gender, training participants by gender, and numbers of technology beneficiaries by gender disaggregation, qualitative data like feed backs and farmers' perception on the technology were taken into account

\subsection{Yield advantage}

Relative Yield advantage of treatments in percentage was estimated using the following simplified formula Yield advantage $\%=$ yield with shelter-yield without shelter $X 100$

Yield without shelter

\subsection{Economic evaluation and analysis}

Costs of production were figured out and recorded and economic return was also evaluated to know economic and financial feasibility of the technology. Costs such as variable costs and fixed costs were recorded and revenue was calculated using the market price at the time of production.

\subsection{Data analysis}

The collected data were analyzed using SPSS and Excel, descriptive statistics such as mean, percentage, table, 
graphs etc

\section{Results and discussion}

\subsection{Effect of plastic shelter on yield of tomato production under rain fed condition}

The use of locally and easily available plastic shelter by tomato producing farmers had considerable effect on yield performance. Yield performance of the two varieties were different with and without shelter. The mean yield of melka shola variety was 255.3 quintals per hectare using shelter and the mean yield of melka salsa variety with shelter was 246.725 quintals per hectare. The average productivity of melkashola without plastic shelter was 128.66 quintals per hectare and melkasalsa without shelter was 115 quintals per hectare. Relative yield performance of production melkasalsa variety using shelter had $114.5 \%$ yield advantage over farmers' normal production without shelter. On the other hand, the yield performance of melkashola variety with shelter had $98.4 \%$ relative yield advantage over production of using the same variety without shelter Yield advantage $(\%)=$ yield with shelter-yield without shelter $X 100$

\section{Yield without shelter}

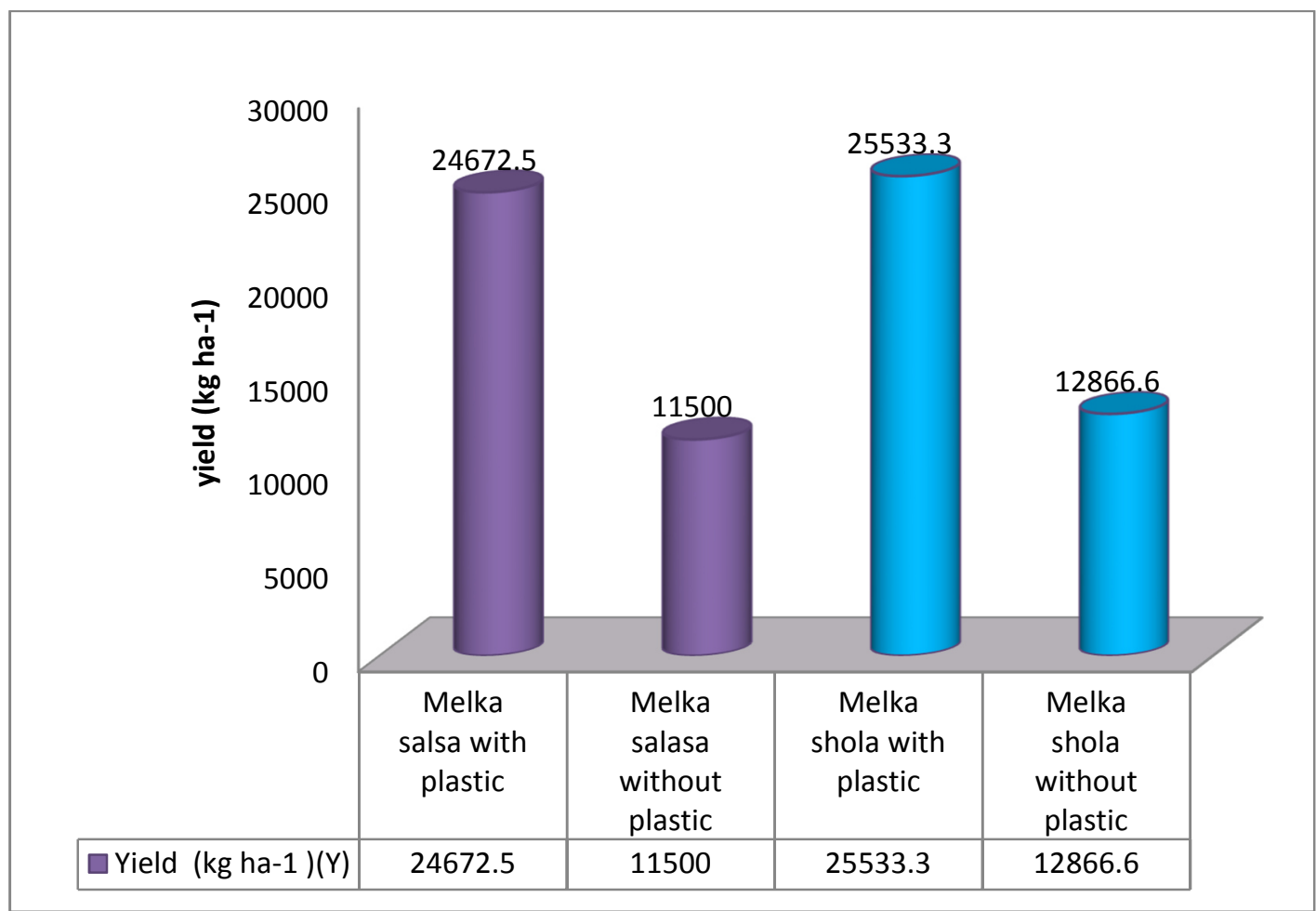

Figure.1. Effect of shelter on yield performance of melkasalsa and melkashola tomato varieties

\subsection{Effect of plastic shelter on net benefit under rain fed production condition}

Melkasalsa variety production using plastic shelter had relative net profit advantage (RPA) of $530 \%$ over without plastic shelter production using the same variety. Similarly, production of melkashola tomato variety using plastic shelter had 35\% relative net profit advantage over without shelter production (see table 1).

RPA $^{*}(\%)=$ profit from with shelter - profit from without shelter * 100

Profit from without shelter

\subsection{Financial analysis (Cost- benefit analysis)}

Production of tomato with plastic shelter is economically viable than without shelter. Both melka shola and melka salsa varities with shelter had better returns than production without shelter. As the result shows a total of 32145 Ethiopian birr per hectare was obtained from production of melkasalsa variety using plastic shelter and 26366.8 Ethiopian birr per hectare from production of melkashola variety with shelter. Production of melkasalsa variety with shelter was six times greater in profitability than production of the same variety without shelter. Similarly, production of melka shola variety using shelter was three times more profitable than without shelter production. See table below 1 . 
Table.1. Records of input costs and benefits of tomato production with and without plastic shelter

\begin{tabular}{|c|c|c|c|c|}
\hline Costs and benefits & $\begin{array}{l}\text { Melka salsa with } \\
\text { plastic shelter }\end{array}$ & $\begin{array}{l}\text { Melka salasa without } \\
\text { plastic shelter }\end{array}$ & $\begin{array}{l}\text { Melka shola with } \\
\text { plastic shelter }\end{array}$ & $\begin{array}{l}\text { Melka shola without } \\
\text { plastic shelter }\end{array}$ \\
\hline Hectare (ha) & 0.04 & 0.04 & 0.04 & 0.04 \\
\hline Yield $\left(\mathrm{kg} \mathrm{ha}^{-1}\right)(\mathrm{Y})$ & 24672.5 & 11500 & 25533.3 & 12866.6 \\
\hline Price $(\mathrm{p})$ & 12 & 12 & 12 & 12 \\
\hline Gross farm gate benefit $\mathrm{GB}=\mathrm{Y} * \mathrm{P}$ & 296070 & 138000 & 296400 & 154399.2 \\
\hline \multicolumn{5}{|l|}{ Variable input costs (VIC) } \\
\hline Labor (birr ha-1) & 108025 & 97000 & 109966.6 & 98999.6 \\
\hline Plastic shelter (birr ha-1) & 117500 & - & 117500 & - \\
\hline Wooden materials (birr ha ${ }^{-1}$ ) & 22500 & - & 26666.6 & - \\
\hline Chemicals (birr ha ${ }^{-1}$ ) & - & 20000 & - & 20000 \\
\hline Total variable input costs (TVIC) & 248025 & 117000 & 254133.6 & 118999.6 \\
\hline \multicolumn{5}{|l|}{ Fixed input costs (FIC) } \\
\hline Cost of land & 1900 & 1900 & 1900 & 1900 \\
\hline Fertilizers (birr ha ${ }^{-1}$ ) & 14000 & 14000 & 14000 & 14000 \\
\hline Total fixed input costs (TFIC) & 15900 & 15900 & 15900 & 15900 \\
\hline $\mathrm{TC}=\mathrm{TVIC}+\mathrm{TFIC}$ & 263925 & 132900 & 270033.6 & 134899.6 \\
\hline Net profit $=$ TR-TC & 32145 & 5100 & 26366.4 & 19499.6 \\
\hline
\end{tabular}

\subsection{Partial budget analysis and marginal rate of return}

Partial budget and marginal rate of return analysis was undertaken to evaluate the economic feasibility of tomato production using plastic shelter production method. As the result indicates plastic shelter method of tomato production was found to be economically viable and cost effective. An investment of 1 ETB (Ethiopian birr) on tomato production using shelter could generate a net income of 20.6 Ethiopian birr in melkasalsa variety whereas 14.36 Ethiopian birr in Melkashola variety. A net income of melkasalsa variety production by using plastic shelter was $27045 \mathrm{ETB}$ on a hectare of land. On the other hand, melkashola tomato variety production with shelter could generate a net income of 17834.2 ETB.

\begin{tabular}{|c|c|c|c|c|}
\hline Items & $\begin{array}{l}\text { Melka salasa } \\
\text { without plastic }\end{array}$ & $\begin{array}{l}\text { Melka salsa } \\
\text { with plastic }\end{array}$ & $\begin{array}{l}\text { Melka shola } \\
\text { without plastic }\end{array}$ & $\begin{array}{l}\text { Melka shola } \\
\text { with plastic }\end{array}$ \\
\hline Hectare (ha) & 0.04 & 0.04 & 0.04 & 0.04 \\
\hline Yield $\left(\mathrm{kg} \mathrm{ha}^{-1}\right)(\mathrm{Y})$ & 11500 & 24672.5 & 12866.6 & 25533.3 \\
\hline Price $(p)$ & 12 & 12 & 12 & 12 \\
\hline Gross benefit, $\mathrm{GB}=\mathrm{Y} * \mathrm{P}$ & 138000 & 296070 & 154399.2 & 296400 \\
\hline Variable Input costs (VIC) & & & & \\
\hline Labor (birr ha-1) & 97000 & 108025 & 10999.6 & 109966.6 \\
\hline Plastic shelter (birr ha- $\left.{ }^{-1}\right)$ & - & 117500 & - & 117500 \\
\hline Wooden materials (birr ha ${ }^{-1}$ ) & - & 22500 & - & 26666.6 \\
\hline Chemicals (birr ha ${ }^{-1}$ ) & 20000 & - & 20000 & - \\
\hline Fertilizers (birr ha ${ }^{-1}$ ) & 14000 & 14000 & 14000 & 14000 \\
\hline Total variable Input costs (TVIC) & 131000 & 262025 & 143966.6 & 268133.2 \\
\hline Net benefit, GB-TVIC & 7000 & 34045 & 10432.6 & 28266.8 \\
\hline $\begin{array}{l}\text { Change in net benefits between two } \\
\text { consecutive treatments }=\Delta \mathbf{N B}\end{array}$ & & 27045 & & 17834.2 \\
\hline $\begin{array}{l}\text { Change in total variable input costs } \\
\text { between two consecutive treatments }= \\
\Delta \text { TVIC }\end{array}$ & \multicolumn{2}{|c|}{131025} & \multicolumn{2}{|c|}{124166.6} \\
\hline Marginal rate of return $=\mathrm{MRR}$ & \multicolumn{2}{|c|}{0.206} & \multicolumn{2}{|c|}{0.1436} \\
\hline
\end{tabular}

a. Change in net benefits of melkasalsa tomato production between with and without plastic shelter, $\Delta \mathrm{NB}=$ 34045-7000 $=27045$ ETB ha ${ }^{-1}$

b. Change in net benefits of melkashola tomato production between with and without plastic shelter, $\Delta \mathbf{N B}=$ 28266.8 -10432.6 = 17834.2 ETB ha ${ }^{-1}$

c. Change in total variable input cost of melkasalsa tomato production between with and without plastic shelter, ATVIC $=262025-131000=131025 E_{T B} h^{-1}$

d. Change in total variable input cost of melkashola tomato production between with and without plastic shelter, $\Delta T \boldsymbol{T I C}=268133.2-143966.6=124166.6 \mathrm{ETB} \mathrm{ha}^{-1}$ 


\subsection{Feedbacks and farmers' preference}

Farmers and stakeholders had given feedbacks on the technologies demonstrated. Those participants gave positive feedbacks on the practice under shelter. Additionally, farmers have been convinced that the practice is economically feasible. This technology had better advantage to produce fresh tomato with high quality and yield in the rainy period

\begin{tabular}{|l|l|l|}
\hline Technology & Ranks & Justification \\
\hline Melkasalsa with shelter & $\mathbf{1}^{\text {st }}$ & Protect disease and pests, higher yield, protect snow \\
\hline Melkasalsa without shelter & $\mathbf{2}^{\text {nd }}$ & Exposed to disease and pests, less yield, doesn't protect snow \\
\hline Melka shola with shelter & $\mathbf{1}^{\text {st }}$ & Protect disease and pests, higher yield, protect snow \\
\hline Melkashola without shelter & $\mathbf{2}^{\text {nd }}$ & Exposed to disease and pests, less yield, doesn't protect snow \\
\hline
\end{tabular}

\section{Conclusion and Recommendation}

Based on the cost benefit and partial budget analysis of this new tomato production method under rain fed condition was economically profitable, is better to produce fresh tomato with high quality and yield in the rainy period, environmentally sound and suitable to human life under farmers circumstances in Fogera plain of tomato production. Fogera plain is suitable for vegetable production including tomato and there for, the stack holders and responsible bodies intensively work on this technology and create linkage among actors in the value chain of tomato production so as to ensure sustainable supply and improvement of farmers livelihood.

\section{References}

Getahun, D (2015). Open Field Performance of Tomato Lycopersicon esculentum Mill.) Varieties in the Rainy season at Woreta, South Gondar, Ethiopia. International Journal Scientific Research in Agricultural Sciences 2(5), pp. 117-125

Getahun,D (2019);Response of Tomato varieties to Rainy season production under low cost plastic Shelter ,International journal of research studies in Agricultural scinces (IJRSAS),5(2)PP1-6.

Palada, M.C., Roan, Y.C., and Black, L.L (2003). Rain shelters for tomato production in the hot-wet season. International Cooperator's Guide, AVRDC Publication Number: 03 